\title{
The Study of Inter-organizational Cooperation in Hospital -A Perspective of Resource-based Theory
}

\author{
Chi-Wen Juan ${ }^{1}$, Hung-Chih Lai ${ }^{2}$, Ying -Chieh LIU ${ }^{3, a}$ and Ping-Liang Chen ${ }^{1}$ \\ ${ }^{1}$ Department of Management, Kuang Tien General Hospital (The Shalu hospital Area), Taiwan \\ ${ }^{2}$ Department of International Business Studies, National Chi Nan University, Taiwan \\ ${ }^{3}$ Associate Professor at Department of Information Management, Chaoyang University of Technology, Taiwan
}

\begin{abstract}
Based on the resource-based theory, this study analyzed cross-organization cooperation and resource value of hospital medical departments in the viewpoint of rare, irreplaceable, and inimitability of a resource base model developed by scholars Grant and Barney. We interviewed 10 respondents in three regional hospitals and analyzed the interview contents according to the model. The important results are twofold: (a) The rare and irreplaceable resources owned by hospitals relate to the competitive advantage of the hospital; (b) Hospital medical collaboration across organizational divisions or self-development and medical divisions in professional competence are positively correlated.
\end{abstract}

\section{Introduction}

A concept, "Hospital Medical Division Collaborating", has become an important managerial strategy for hospitals. This study was based on a study by [1] who established a medical research model of resources value and rareness for across-organizations of medical divisions. There are differences between various types of hospitals in the domestic medical organizations. Based on the relation-ships between the use of medical acrossorganizational cooperation model and the resource-based theory, the research propositions can be developed. They are LVLR - LVHR - HVLR and HVHR (they will be explained in the following sections).

\section{Literature review}

\subsection{Across organizational cooperation of medical divisions}

Charles and Essinger [2] developed the outsourcing model based on the service agreement and the responsibilities of the third party. Outsourcing is known as companies are entrusted to external organizations for their parts of business processes. Out-sourcing is the appropriate allocation of company's technologies and resources to produce the maximum benefit. Companies focus on its core business and outsource other unimportant activities ([3]).
Barney [1] pointed out that for achieving lasting competitive advantages, an organization's resources must have characteristics of value and rareness. Overall, resource-based theory is particularly focus on the resources which have the following characteristics: value, rareness, inimitability and irreplaceable. Enterprises are able to create sustainable competitive advantage by resources with these characteristics.

\subsection{Value and rareness integration model}

We adopted the value and rareness model in re-sourcebased view to discuss across-organizational cooperation of medical divisions. The definitions in value and rareness of this study are as follows. First, value means a company's existing resources which create performance for companies. Second, rareness means currently only a few competitors have the re-sources in the market, but the owner amounts of the resources in the market are less than the demands. Resources have both characteristics of value and rareness or have either are important for acrossorganizational cooperation (Figure 1).

\subsection{Resources based view}

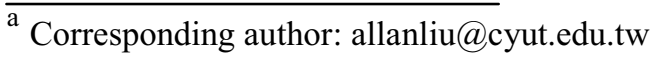


(Value)

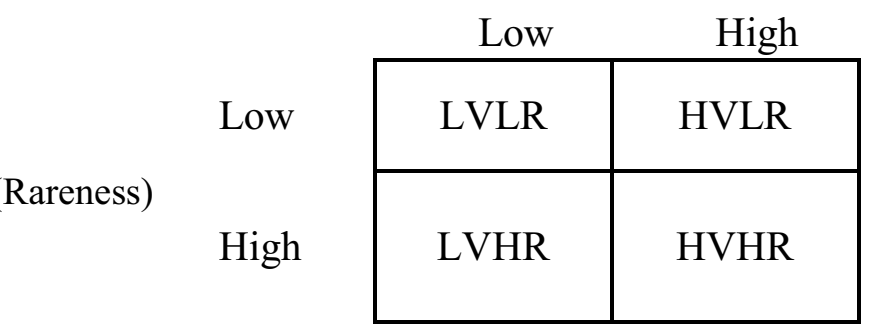

Figure 1. Medical across-organizational cooperation model.

HVHR: resources are with high value and high rareness. These are the hospital's core resources which have a high degree of sustaining competitive ad-vantage and are rare in the market.

LVHR: resources are with low value and high rareness. These contribute less to hospital, and are rare in the market.

HVLR: resources are with high value and low rareness. These contribute to the maintenance of competitive advantages but are not rare in the market.

LVLR: resources are with low value and low rareness. These contribute less to maintain competitive advantages for hospitals and are common resources in the market.

\section{Research methodology}

To understand the impacts of resources on the cooperation of across organizations, we collected information by in-depth interviews which consisted of three parts: pre-visit interview, interview and data analysis.

The interviewees were the heads or directors of the regional hospital or the competent outsourcing medical divisions. Because they can provide a wealth of health related problems while they are operating di-visions, and the problems with across-organizational cooperation. We have interviewed 10 respondents in three hospitals. Table 1-3 show their information.

Table 1. A hospital respondents and time

\begin{tabular}{|l|l|l|l|l|}
\hline $\begin{array}{l}\text { Hospital lieu } \\
\text { of that }\end{array}$ & A General & A branch & A branch & A branch \\
\hline Respondents & Director Ho & $\begin{array}{l}\text { Lee Nursing } \\
\text { length }\end{array}$ & Premier Lee & Director Su \\
\hline Established & 1913 & 1996 & 2006 & 2006 \\
\hline $\begin{array}{l}\text { Hospital } \\
\text { location }\end{array}$ & Shalu & Dajia & Tunghsiao & Tunghsiao \\
\hline Hospital grade & $\begin{array}{l}\text { Regional } \\
\text { Teaching }\end{array}$ & $\begin{array}{l}\text { Regional } \\
\text { Teaching }\end{array}$ & $\begin{array}{l}\text { Regional } \\
\text { Hospital }\end{array}$ & $\begin{array}{l}\text { Regional } \\
\text { Hospital }\end{array}$ \\
\hline $\begin{array}{l}\text { Hospital } \\
\text { Ownership }\end{array}$ & $\begin{array}{l}\text { Corporation } \\
\text { aggregate }\end{array}$ & $\begin{array}{l}\text { Corporation } \\
\text { aggregate }\end{array}$ & $\begin{array}{l}\text { Corporation } \\
\text { aggregate }\end{array}$ & $\begin{array}{l}\text { Corporation } \\
\text { aggregate }\end{array}$ \\
\hline $\begin{array}{l}\text { Preparation of } \\
\text { beds }\end{array}$ & 657 & 473 & 50 & 50 \\
\hline $\begin{array}{l}\text { Interview } \\
\text { Time }\end{array}$ & 90 minutes & 85 minutes & 100 minutes & 95 minutes \\
\hline
\end{tabular}

Table 2. B hospital respondents and time

\begin{tabular}{|c|c|c|c|c|}
\hline Hospital, lieu of that & B Branch & B Branch & B Branch & B Branch \\
\hline Respondents & $\begin{array}{l}\text { Wang } \\
\text { Director }\end{array}$ & Minister Li & $\begin{array}{l}\text { Chen } \\
\text { Commissioner }\end{array}$ & $\begin{array}{l}\text { Director } \\
\text { Wang }\end{array}$ \\
\hline Established & 1980 & 1980 & 1980 & 1980 \\
\hline Hospital location & Nantou & Nantou & Nantou & Nantou \\
\hline Hospital grade & $\begin{array}{l}\text { Regional } \\
\text { Hospital }\end{array}$ & $\begin{array}{l}\text { Regional } \\
\text { Hospital }\end{array}$ & $\begin{array}{l}\text { Regional } \\
\text { Hospital }\end{array}$ & $\begin{array}{l}\text { Regional } \\
\text { Hospital }\end{array}$ \\
\hline Hospital Ownership & $\begin{array}{l}\text { Corporation } \\
\text { aggregate }\end{array}$ & $\begin{array}{l}\text { Corporation } \\
\text { aggregate }\end{array}$ & $\begin{array}{l}\text { Corporation } \\
\text { aggregate }\end{array}$ & $\begin{array}{l}\text { Corporation } \\
\text { aggregate }\end{array}$ \\
\hline Preparation of beds & 214 & 214 & 214 & 214 \\
\hline Interview Time & 70 minutes & 100 minutes & 60 minutes & 90 minutes \\
\hline
\end{tabular}

Table 3. C hospital respondents and time

\begin{tabular}{|l|l|l|}
\hline Hospital, lieu of that & C General Hospital & C General Hospital \\
\hline Respondents & Chen, vice president & Director Chen \\
\hline Established & N.A & N.A \\
\hline Hospital location & Taichung & Taichung \\
\hline Hospital grade & Regional Teaching & Regional Teaching \\
\hline Hospital Ownership & Corporation aggregate & Corporation aggregate \\
\hline Preparation of beds & 653 & 653 \\
\hline Interview Time & 120 minutes & 80 minutes \\
\hline
\end{tabular}

\section{Analysis results}

\subsection{HVHR}

When hospitals with high value and rareness, they would like to adopt their own development in-stead of cooperate with others.

"We have established over 100 years as public health in the central coastal line Tunghsiao, Dajia and Shalu area. We have grown up by more than one thousand beds and have reached three thou-sand beds so far. We have a total of five different branches. (An orthopedic surgeons)"

Proposition 1: Hospital divisions which have high value and rareness are more likely to adopt their own development.

\subsection{LVHR}

These resources contribute less to hospitals' competitive advantages when hospitals have resources with low-value and high rareness.

"Our hospital's dialysis department is basically the same as other hospitals in terms of equipment, technology or mode of operation. The difference is the convenience for the people in this region. We are the only renal dialysis department in the region. Each patient is charged 5,000NT when they do dialysis treatment. If they do too much, the fixed costs would increase and the profit would be reduced. Our economic size is not as large as Chang Gung Memorial Hospital, and our human re-sources are not very enough, often physician man-power faults occur. (A branch of Premier Lee)"

Proposition 2: hospital medical divisions which have high rareness and low value are more likely to take across organizational cooperation. 


\subsection{HVLR}

When hospitals have resources with high value and low rareness, these resources are able to create competitive advantages for hospitals. Thus, they prefer to develop by their own.

"Our hospital does not invest on or develop specialized equipment only for dialysis operation, be-cause dialysis equipment is almost the same be-tween different hospitals. Dialysis treatment is a standard operation. Each hospital can set up and operate the equipment appropriately. The threshold is not high, so we can develop by ourselves. (A Branch Director Wang) “

Proposition 3: hospital medical divisions which have high value and low rareness are more likely to take their own development.

\subsection{LVLR}

When hospitals have resources with low value and low rareness, these resources fail to create competitive advantages for hospitals.

"If the laboratory area hospitals are not the most unique and with good reputation, unless they are special hospitals like psychiatric hospitals, they would proceed across-organizational cooperation, like Taipei Wan Fang Hospital's laboratory. The hospitals would depend on inter-organizational co-operation to achieve higher performance than those do not pursue acrossorganizational co-operation. The efficiency improvement of the cooperation weighs the cost reduction. Interorganizational cooperation is often more efficient than a single hospital. Such as the purchase procedures of hospitals are often a period of assessment. Through interorganizational cooperation, the purchases procedures can be completed within a few days, as our equipment or multi-mode operation are about the same. (A Branch Director Li) “

Proposition 4: hospital medical divisions which have low value and low rareness are more likely to take acrossorganizational cooperation.

\section{Conclusions}

This study concluded the followings:

(A) Medical division value and other core competencies are positively related to the value of hospitals and medical divisions when the hospitals own more core competence.

Core competence is the set of medical subjects including skills and knowledge, not products and capabilities. A flexible and long-term mature platform is able to adapt to the challenges of a changing environment. Core competence is a combination of cross-business sector capacity in enterprises, but also various business sectors have the skills, knowledge, interact with each other and the result of integration. These results need to constantly stick together to business, in-vestment and commitments. So when the medical divisions of the hospital have resources with more value, it would enhance the competitive-ness of the hospital. Interview data showed that medical division with the higher value of the hospital when the hospital owns more core competence.

(B) The irreplaceable and rare resources owned by hospitals relate to the competitive advantage of the hospital.

Other hospitals have the resources with same value are not competitors. In factor markets, demands are more than the supply of the resources, and therefore valuable resources can produce more competitive advantages. Furthermore, competitive advantages can be converted into customer values, which is one of the key functions of resources. Hospitals must consider the value of resources, but also must consider the scarcity of resources. Emphasizing the role of market-based assets, the scarce of resources is one of the elements to maintain competitive advantages. Hospital's scarce resources used in across organizations come from somewhere, because there are a lot of ways including many domestic and international relevance of the research. Through in-depth interviews, this study found that hospital's medical divisions have more resources with higher values, the more competitive advantages the medical department have.

(C) Hospital medical collaboration acrossorganizational divisions or self-development and medical divisions in professional competence are significantly positive correlated.

There are many domestic and foreign scholars pointed out: the more the higher degree of in-house expertise, the higher tendency to self-development of internal system (insourcing) when in-sufficient capacity is more. Its purpose is nothing more than a cost-effective, complementary technology, flexibility of response and the development of core business issues. Through indepth interviews, this study found that hospital medical collaboration across organizational di-visions or selfdevelopment and medical divisions in professional competence are significantly positive correlated

(D) Health department and other areas of the hospital where the value is related to the medical divisions with the higher value of the region when hospitals have more abilities.

In addition to considering the profitability of the decisions whether cooperating with other divisions, hospitals should pay more attention in the medical branches of their local roles, especially the regional hospitals. They cannot simply be measured by the costeffectiveness. The future operation strategy should be evaluated seriously. Through in-depth interviews, this study found that the same amount of scholars and foreign re-search paper, all noted the hospital therapy department of the region, the higher the value of the more part of the core capacity of the hospital.

(E) That medical divisions across organizations quickly acquire technology does not exist within hospitals. 
In recent years, although the quality of care for people's attention, and when the domestic and foreign medical department and other equipment and technology are more advanced, hospitals currently have insufficient intentions to adapt them. It may due to hospitals consider the cost and capabilities of developed technologies. Through in-depth interviews, this study found that the same number of scholars and foreign re-search paper reported that outsourcing is a quick way to get into the advanced technology.

\section{References}

1. J. Barney, J, J. Manag, 17, 1, 99-120 (1991)

2. L. G. Charles., J. Essinger. Inside out-sourcing: The insider's guide to managing strategic sourcing (Naperville, Brealey Pub, 2000)

3. J. B. Quinn., F.G. Hilmer, Sloan. Manage. Rev, Summer, 43-55 (1994) 